\title{
ENCEPHALITIS AND THROMBOCYTOPENIC PURPURA AFTER RUBELLA
}

\author{
BY \\ EMIL STEEN and K. H. TORP \\ From the Paediatric and Epidemiology Department, Ulleval Hospital, Oslo, Norway
}

(RECEIVED FOR PUBLICATION JULY 5, 1956)

Rubella is commonly considered a disease with a short and mild course and few complications except the lesions and malformations found in children whose mothers had rubella during the first months of pregnancy. Therefore it has been regarded as an advantage to girks to acquire this disease before puberty.

In recent years, however, an increasing number of reports has been published dealing with serious complications after rubella. The patients with this diagnosis admitted to the Paediatric and Epidemiology Department, Ulleval Hospital, during the summer of 1955 showed an extraordinarily high incidence of encephalitis and thrombocytopenia.

The characteristic of rubella given in textbooks as a harmless disease, therefore, should be regarded with some reservation.

\section{Encephalitis}

Case 1. K.A.E., a 9-year-old boy, had been in good health until April 26, 1955, when he got catarnal symptoms, post-occipital adenitis, and an eruption typical of rubella. The rash and fever disappeared within 48 hours, and the boy remained well until May 1. He then complained of headache accompanied by nausea, and vomited repeatedly. He was admitted to the hospital on the same day because of a sudden attack of unconsciousness and right-sided convulsions.

On admission he was deeply drowsy and completely unresponsive. He had continuous slight convulsions in the face and the right part of the trunk. There was no nuchal rigidity or stiffness of the back, no change in refiexes and no paresis. Urine analysis, a complete blood cell count and the sedimentation rate on admission were within normal limits. The spinal fluid was clear, colourless and contained 22 cells per c.mm., predominantly lymphocytes. The spinal sugar level was $106 \mathrm{mg}$. per $100 \mathrm{ml}$. (blood sugar $222 \mathrm{mg}$. per $100 \mathrm{ml}$.) and total protein $31 \mathrm{mg}$. per $100 \mathrm{ml}$.

For the first 12 hours the boy remained unconscious and had repeated attacks of generalized convulsions, then he recovered rapidly. Twenty-four hours after admission a detailed neurological examination disclosed nothing abnormal, except some rigidity of the neck.
The spinal fluid was re-examined on May 16. The cell count was 5 per c.mm., sugar $42 \mathrm{mg}$. per $100 \mathrm{ml}$. and total protein $41 \mathrm{mg}$. per $100 \mathrm{ml}$. The patient was discharged on May 20, 1955, completely free from symptoms.

Electroencephalography (Dr. Birger R. Kaada) was carried out three times during the illness. On May 2, the day after admission, the dominating feature was a generalized ihythmic delta-theta activity particularly of frequency of 2-3 per second waves of high amplitude (Fig. 1). These waves were slightly more prominent on the left hemisphere than on the right side. No spikes or sharp waves were seen. The E.E.G. was on the whole of the same type as that recorded in patients suffering from rather severe meningo-encephalitis. At the examination on May 12 the E.E.G. abnormalities were considerably reduced; some abnormal slow wave activity was, however, still visible. Thirty-eight days later the E.E.G. was practically within normal limits (Fig. 1, right part).

In two other patients, a 9-year-old boy and a 10-yearold girl, the same complication was seen. The girl revealed involvement of the central nervous system four days after the rash appeared. The boy suffered first from headache accompanied by nuchal rigidity and stiffness of the back. Two days later a typical rubella eruption appeared. In both these patients the marked drowsiness was the most striking sign. They also had nausea, vomiting and headache. The cell count of the spinal fluid was moderately elevated, the spinal sugar concentration within normal limits. There were no focal symptoms from the central nervous system. In 48 hours the children had recovered completely.

In Norway Motzfeldt (1933), Hagemann (1946), Njå (1946) and Gadeholt and Grimstvedt (1956) have reported one case each of encephalitis following rubella; all four patients died.

In the available literature we have found 88 definite cases of rubella-encephalitis (de Gennes, Célice and Gautreau, 1934; Rodriguez, Gomensoro, Rodriguez Barrios and Acevedo de Mendilaharsu, 1947; Vestergaard, 1949; Borch Jørgensen, 1955; Schleisner, Thorsteinsson and Begeskov-Jensen 1955). Schleisner and his colleagues have studied the literature in detail up to 1955.

Rubella generally has a mild course and registra- 
tion is, when done, very unsatisfactory. It is therefore impossible to calculate the real incidence of complicating encephalitis, but, judging from the literature, it must be rare. Margolis, Wilson and Top (1943) observed 14 patients with encephalitis during an epidemic in Detroit comprising about 9,000 cases of rubella.

The incidence must be expected to be higher in hospital material because patients with encephalitis need hospital care. Bénard (1921) reported 13 cases of encephalitis in 291 hospital patients with rubella. Our three cases were observed among 21 patients admitted for rubella in the period May to August, 1955. These 21 patients, however, are but a small proportion of the real number of cases in Oslo city during the same period, because patients with rubella are not usually admitted to hospital.

The symptoms of encephalitis most frequently appear in the first week after the rash. Cases have been reported, however, in which encephalitis has preceded the exanthema for two to nine days (Zadik, 1927; de Gennes et al., 1934; Rodriguez et al., 1947; Holliday, 1950). This happened in one of our patients.

A typical feature is that consciousness is seriously reduced (Borch Jørgensen, 1955). Coma may occur in a few hours, lasting up to three to four days.
Various focal symptoms may be seen. Most frequently they are transitory, however. Usually the symptoms of encephalitis disappear completely within a few hours or days, though permanent sequelae have been observed (Davison and Friedfeld, 1938; Vestergaard, 1949).

Death occurred in 17 of the 88 cases studied in the literature, all during the acute stage within a week after the onset of encephalitis. Most of the fatal cases showed pronounced hyperpyrexia.

Post-mortem examinations have revealed only non-specific findings in the central nervous system (Motzfeldt, 1933; Briggs, 1935; Taylor, 1937; Davison and Friedfeld, 1938; Margolis et al., 1943; Njẳ, 1946; Mitchell and Pampiglione, 1954). In general no demyelinization has been found (Mitchell and Pampiglione, 1954). Accordingly persistent sequelae are extremely rare in rubella encephalitis. This contrasts markedly with the widespread demyelinization in encephalitis after measles and varicellae.

Therapy is symptomatic, with special care of respiration, bladder function, nutrition and fluid balance. Because the prognosis may be favourably influenced by anti-fever treatment in cases with hyperpyrexia (Schleisner et al., 1955), cortisone, chlorpromazine, ice-bags, etc., should be tried.

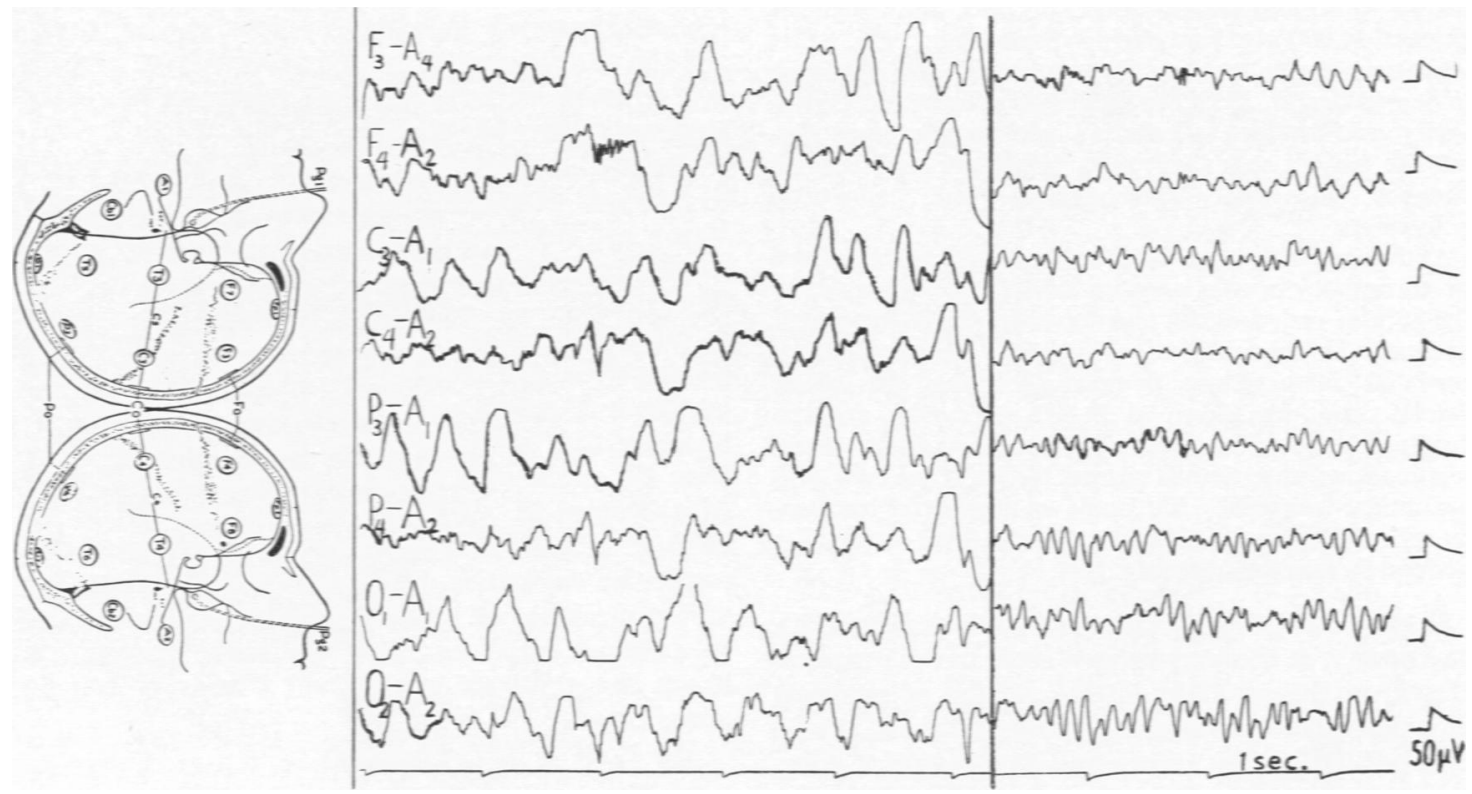

FK. 1.-Electroencephalographic records in Case 1.

Left: E.E.G. obtained on May 2, 24 hours after the onset of clinical symptoms of encephalitis. The dominating feature is a generalized rhythmic delta-theta activity.

Right: E.E.G. examination on June 20 , with practically normal tracing. 


\section{Thrombocytopenic Purpura}

Another complication of rubella is thrombocytopenia. Among the 21 patients in the present material two developed thrombocytopenic purpura and one of them needed repeated blood transfusions.

Case 2. M.V., a 7-year-old girl, had previously suffered from mumps, measles and non-paralytic poliomyelitis. On August 3, 1955, she developed catarrhal symptoms, post-occipital adenitis, and a rash typical of rubella. Several of her friends had rubella at the same time. On August 5 a cut was made in the lobule of the ear to perform a haemoglobin test, but the lesion continued bleeding for more than an hour. The next day multiple ecchymoses appeared on the legs, and a haematoma developed on the right upper eyelid. No drugs had been used.

On August 7, 1955, four days after the rubella eruption, she was admitted to hospital with profuse nasal haemorrhage. She had a generalized purpuric rash with numerous ecchymoses and petechial haemorrhages. The spleen and liver were not enlarged. There was no haematuria, but tests for blood in the stool were strongly positive. The haemoglobin value was $62^{\circ}{ }_{0}$, red blood cell count $3 \cdot 2 \mathrm{~m}$. per c.mm., platelet count 16,200 per c.mm., bleeding time more than 15 minutes, coagulation time 4 minutes and prothrombin value $98^{\circ}$.

The nasal haemorrhage required packing of the nose. She was further treated with blood transfusions and cortisone ( $1.25 \mathrm{~g}$. in 12 days). The tendency to haemorrhage slowly subsided in the course of three weeks. A relapse with nasal haemorrhage, purpura and a platelet count of 54,000 occurred early in September, 1955. The patient was again treated with cortisone. On discharge on September 15, 1955, she was well. Control examinations, however, have revealed a slight thrombocytopenia, and the patient still (February, 1956) has an increased tendency to nasal haemorrhages and cutaneous ecchymoses.

At the same time another girl, 4 years old, was admitted for thrombocytopenic purpura associated with rubella. The rubella rash and the haemorrhages appeared simultaneously in this patient. No drugs had been used. Repeated examinations demonstrated that the blood platelet count was down to 39,500 per c.mm., and the bleeding time was more than 15 minutes. Other blood examinations were within normal limits. The course in this patient was mild. She made an uneventful recovery but when discharged after four weeks there was still a moderately lowered platelet count.

Slight thrombocytopenia without clinical purpura may be seen at the beginning of most of the common infectious diseases (Olef, 1936). Cases of manifest purpura due to thrombocytopenia have been reported in measles (McLean, Kreidel and Caffey, 1932; Patek, 1936; Rosenthal, 1939), in varicellae (Stoesser and Lockwood, 1938), in infectious mononucleosis (Rosenthal, 1939; Lloyd, 1944) and in acute respiratory infections (McLean et al., 1932).
Fifteen proven cases of thrombocytopenic purpura after rubella have been found in the literature available (Gunn, 1933; Fox and Walton, 1946; Magnusson, 1946; Njå, 1946; Warren, Rogliand and Potsubay, 1946; Ginsberg and Wilson, 1947: Ackroyd, 1949; Freedman and Laderman, 1949). It should be emphasized, however, that purpura in rubella may be seen without pathological changes in the blood platelet count (Ström, 1940; Ackroyd, 1949).

Because rubella often gives such slight symptoms that it may be overlooked, it seems possible that some cases of 'cryptogenetic' purpura are in reality due to rubella. This complication, therefore, may be more frequent than indicated in the literature. In support of this assumption is our demonstration of thrombocytopenia in six other patients who suffered from rubella during a stay in the Paediatric Department. The platelet count in these cases varied between 22,000 and 132,000 per c.mm. during the first week after the onset of the exanthema. There was no purpura.

If thrombocytopenia is confirmed to be relatively frequent in epidemics of rubella this finding may be of diagnostic value. Our observations, however, are too few to permit of any definite conclusions.

The clinical and laboratory examinations reveal the same changes as those found in other forms of purpura caused by thrombocytopenia. The bleeding tendency generally subsides in a few days or weeks, and the patient usually recovers completely. Death due to cerebral haemorrhage, however, has been reported (Ackroyd, 1949).

There is no causal treatment. Cortisone ought to be tried. Repeated transfusions of freshly drawn blood are indicated to replace any loss in blood volume, and may contribute to haemostasis (Evans, 1956).

The five cases reported occurred in 21 patients admitted to the hospital for rubella. This high incidence of grave complications naturally raises the question that a virus strain of special virulence has been the cause, analogous to that seen in epidemics of poliomyelitis. It has also been observed previously that complications may be more frequent in particular epidemics of rubella (Neal, 1942). The varied incidence of rubella embryopathies observed in different countries may also cause speculation about the existence of different strains of rubella viruses.

\section{Summary}

Three cases of encephalitis and two cases of thrombocytopenic purpura in 21 patients with rubella are reported. The literature concerning these complications is reviewed. 


\section{REFERENCES}

Ackroyd, J. F. (1949). Quart. J. Med., 42 (n.s. 18), 299.

Bénard, R. (1921). Bull. Soc. méd. Hôp., Paris, 45, 1443.

Borch Jergensen, M. (1955). Danish med. Bull., 2, 106.

Briggs, J. F. (1935). J. Pediat., 7, 609.

Davison, C. and Friedfeld, L. (1938). Amer. J. Dis. Child., 55, 496.

Evans, R. S. (1956). Blood, 11, 386.

Fox, M. J. and Walton, W. P. (1946). Marquette med. Rev., 11. 208. Cited by Ackroyd (1949).

Freedman, M. and Laderman, P. 1949). Arch. Pediat.. 66, 135.

Gadeholt, H. and Grimstvedt, M. (1956). Nord. Med., 55, 594.

Gennes, L. de, Célice and Gautreau (1934). Bull. Soc. med. Hóp. Paris, 50, 1113

Ginsberg, H. S. and Wilson, J. M. (1947). Amer. J. Med.. 3, 652.

Gunn, W. (1933). Brit. J. Child. Dis., 30, 111.

Hagemann, O. (1946). T. norske Laegeforen., 66, 561.

Holliday, P. B. (1950). J. Pediat., 36, 185.

Lloyd, P. C. (1944). Amer. J. med. Sci., 207, 620.

McLean, S., Kreidel, C. and Caffey, J. (1932). J. Amer. med. Ass., 98. 387.

Magnusson, J. H. (1946). Acta med. scand., 126. 40.
Margolis, F. J., Wilson, J. L. and Top, F. H. (1943). J. Pediat., $23,158$.

Mitchell, W. and Pampiglione, G. (1954). Lancet, 2. 1250

Motzfeldt, K. (1933). Norsk Mag. Laegevid., 94. 153.

Neal, J. B. (1942). Encephalitis. New York.

Nja, A. (1946). T. norske Laegeforen., 66. 775.

Olef, I. (1936). Arch. intern. Med., 57, 1163.

Patek, A. J., Jr., (1936). Amer. J. med. Sci., 191. 723.

Rodriguez, B.. Gomensoro, J. B., Rodriguez Barrios. R. and Acevedo de Mendilaharsu, S. (1947). Arch. urug. Med., 31, 223. Cited by Mitchell and Pampiglione (1954).

Rosenthal, N. (1939). J. Amer. med. Ass., 112, 101

Schleisner, P., Thorsteinsson, J. and Begeskov-Jensen, I. (1955). Danish med. Bull., 2, 101.

Stoesser, A. V. and Lockwood, W. W. (1938). J. Pediat., 12, 641.

Ström, j. (1940). Acta med. scand., 105, 160

Taylor, R. J. (1937). Med. J. Aust., 2. 604.

Vestergaard, E. (1949). Encefalitis. Thesis, Copenhagen University. Nyt Nordisk Forlag. Copenhagen.

Warren, H. D., Rogliand, F. T. and Potsubay, S. F. (1946). Med. Clin. N. Amer., $30,401$.

Zadik, P. (1927). Disch. med. Wschr., 53. 412. 